\title{
Biodiversity of multiple Pregnancy-Associated Glycoprotein (PAG) family: gene cloning and chorionic protein purification in domestic and wild eutherians (Placentalia) - a review
}

\author{
Bozena SzAFRANSKA*, Grzegorz PANASIEWICZ, Marta MAJEWSKA \\ Department of Animal Physiology, Faculty of Biology, University of Warmia and Mazury, \\ Oczapowskiego Str 1A/222, 10-719 Olsztyn-Kortowo, Poland
}

(Received 13 October 2005; accepted 26 April 2006)

\begin{abstract}
This review presents a broad overview of chorionic glycoproteins encoded by the Pregnancy-Associated Glycoprotein (PAG) gene family and also serves to illustrate how the recent discovery of the PAG family has contributed to our general knowledge of genome evolution, placental transcription and placental protein expression. The complex and large PAG family is restricted to the Artiodactyla order, although single PAG-like genes have also been identified in species outside the Artiodactyla. The PAGs are members of the aspartic proteinase (AP) superfamily. Unexpectedly, however, some members of the PAG family possess amino acid substitutions within and around the active site that likely render them unable to act as proteinases. This paper summarises the available information regarding biodiversity of PAG gene expression based on cDNA cloning, mRNA localisation studies and the structural organisation of the PAG genes with a particular emphasis on PAG promoters. It also compares available data regarding PAG protein purifications, sequencing and their $\mathrm{N}$-glycodiversity. Finally, it discusses the scientific relevance, possible functional roles of the PAGs and describes possible profitable applications related to the detection of PAG proteins in the blood of pregnant domestic and wild species.
\end{abstract}

chorionic glycoproteins / eutherian PAG family / diagnostic PAG markers

Abbreviations: AP: Aspartic Proteinases; cDNA: complementary DNA; cRNA: complementary RNA; CG: mammalian Chorionic Gonadotrophin; eCG: equine CG; hCG: human CG; LH: Luteinising Hormone; PAG: Pregnancy-Associated Glycoprotein family; bPAG: bovine PAG (Bos taurus); bubPAG: buffalo PAG (Buffalo bubalis); cPAG: caprine PAG; CdPAG: dromader PAG (Camelus dromedarius); CfPAG: two-humped camel PAG (Camelus ferrus); ePAG: equine PAG; EbPAG: European bison PAG (Bison bonasus L.); fPAG: feline PAG (Felis catus); LpPAG: alpaca PAG (Lama pacos); oPAG: ovine PAG (Ovis aries); pPAG: porcine PAG (Sus scrofa domestica); wtdPAG: white tail deer PAG (Odocoileus virginianus); zPAG: zebra PAG (Equus zebra-mountain zebra); zebuPAG (Bos indicus); pBP: porcine Basic Protein; $\mathrm{PGF}_{2 \alpha}$ : prostaglandin $\mathrm{F}_{2} \alpha$; PSP60: $60 \mathrm{kDa}$ Pregnancy Serum Protein; Prl: prolactin; PSPB: Pregnancy Specific Protein B family; bPSPB: bovine PSPB; ePSPB: elk PSPB; mPSPB: moose PSPB; SBU3: oPAG proteins with specific oligosaccharide epitopes; RPA: Ribonuclease Protection Assay; tsp: transcription start point.

*Corresponding author: szafran@uwm.edu.pl 


\section{IDENTIFICATION HISTORY AND EVOLUTIONARY CONSERVATION OF THE PAG FAMILY}

The PAGs, comprise a large group of placental AP superfamily that are expressed in pre-placental trophoblast (TR) and after implantation in the trophectoderm (TRD) - the chorionic epithelium of eutherian mammals (Placentalia) with different placenta types. The first member of the family was described by Butler et al. [1] and was given initially the name pregnancy specific protein B (PSPB) in bovine placenta. Subsequent work by other research groups identified related proteins, which were given names such as PAGs [2,3], $60 \mathrm{kDa}$ - pregnancy serum protein (PSP60) [4], or SBU3 [5] in ruminant ungulates (see Sect. 2.4, 2.5 and 2.7). These PAG/PSPB/PSP60/SBU3 proteins are detectable in maternal blood and were reported to be useful as prenatal markers for pregnancy diagnoses in various domestic and wild ruminants (see Sect. 2.8).

The first PAGs to be cloned were from cattle (bPAG1) and sheep (oPAG1) [2]. Later, related genes were described in pigs; these were named porcine (p) PAG1 and pPAG2 [6] and they represent two pPAG1and 2-like subfamilies that have since been shown to include additional PAG members, including pPAG3-6, pPAG8 and pPAG10 [7, 8]. Ruminants and pigs are even-toed ungulates (Artiodactyla order), but they have strikingly different placenta types (synepitheliochorial cotyledonary and epitheliochorial diffuse, respectively). Not surprisingly, a range of PAG forms, unique to each placenta type, have been identified in artiodactyls, however, single PAG-like genes have also been reported in non-artiodactyls with another placenta type (Tab. I). Moreover, Southern analysis of genomic DNA (gDNA) provides the means to study the presence of
PAGs in the genomes of various wild ruminants: gaur, moose, mule deer, gnu, yak, buffalo, impala, goral, etc. [9]. Unfortunately, the cDNA of PAGs have yet to be cloned from most of these species.

Phylogenetic analyses of PAG and PAGlike genes indicated that the PAG family originates from an ancient PAG-like precursor (pro-gene) by duplication and positive selection approximately 86 million years ago [18-20], which is consistent with estimates for the split of the artiodactyls from other ungulate orders. The conservation and homology of the PAG in many eutherians (Artiodactyla, Perissodactyla, Carnivora and Rodentia) is suggestive of their importance in the reproductive physiology of ungulate species.

\section{BIODIVERSITY OF IDENTIFIED MULTIPLE PAG GENES, TRANSCRIPTS, PROTEINS AND THEIR CLASSIFICATION}

The PAGs belong to the AP superfamily (EC 3.4.23), which includes proteolytic enzymes present in vertebrates and non-vertebrates. Examples include the following: pepsin A, C, F (EC 3.4.23.1, EC 3.4.23.3, EC 3.4.23.-), aspergillopepsin (EC 3.4.23.18), candidopepsin (EC 3.4.23.24), chymosin-preprorenin (EC 3.4.23.4), renin (EC 3.4.23.15), cathepsin D (EC 3.4.23.5) and cathepsin E (EC 3.4.23.34). The AP superfamily also includes parasite plasmepsins (EC 3.4.23.38 and EC 3.4.23.39) as well as several other fungal and retroviral enzymes.

\subsection{Cloned cDNAs and their in silico translation to full-length polypeptide PAG precursors}

Multiple PAG genes have been cloned and identified in Artiodactyla: domestic, wild ruminants and pigs (Tab. I). All 
Table I. Cloned cDNA of the PAG gene family, chronologically deposited in the international GenBank database.

\begin{tabular}{|c|c|c|c|c|c|}
\hline$\overline{\text { Name }}$ & $\begin{array}{l}\text { Accession } \\
\text { numbers to } \\
\text { deposited cDNA }\end{array}$ & $\begin{array}{l}\text { Coded } \\
\text { polypeptide } \\
\text { precursors (aa) }\end{array}$ & $\begin{array}{l}\text { Transcripts } \\
\text { (day of } \\
\text { pregnancy) }\end{array}$ & Species & $\begin{array}{l}\text { Identified } \\
\text { by }\end{array}$ \\
\hline$\overline{\text { oPAG1 }}$ & M73961 & 382 & 100 & Sheep & \multirow{2}{*}[2]{} \\
\hline bPAG1* & M73962 & 380 & 260 & Cattle & \\
\hline bPAG2 & 06151 & 376 & 260 & Cattle & [10] \\
\hline pPAG1 & L34360 & 389 & $13-17$ & \multirow[t]{2}{*}{ Pigs } & \multirow[t]{2}{*}{ [6] } \\
\hline pPAG2* & L34361 & 387 & $13-17$ & & \\
\hline oPAG2 & U30251 & 376 & 13 & \multirow{8}{*}{ Sheep } & \multirow{8}{*}[9,11]{} \\
\hline oPAG3* & U94789 & 380 & 100 & & \\
\hline oPAG4 & U94790 & 380 & 100 & & \\
\hline oPAG5 & U94791 & 379 & 100 & & \\
\hline oPAG6 & U94792 & 380 & 100 & & \\
\hline oPAG7* & U94793 & 380 & 100 & & \\
\hline oPAG8 & U94794 & 341 & 100 & & \\
\hline oPAG9 & U94795 & 346 & 100 & & \\
\hline bPAGv-3 & L06153 & 381 & 260 & \multirow{10}{*}{ Cattle } & \multirow{10}{*}{ [9] } \\
\hline bPAG4* & AF020506 & 380 & 25 & & \\
\hline bPAG5 & AF020507 & 377 & 25 & & \\
\hline bPAG6* & AF020508 & 379 & 25 & & \\
\hline bPAG7* & AF020509 & 341 & 25 & & \\
\hline bPAG8 & AF020510 & 387 & 25,19 & & \\
\hline bPAG9 & AF020511 & 379 & 25,19 & & \\
\hline bPAG10 & AF020512 & 380 & 25 & & \\
\hline bPAG11 & AF020513 & 376 & 25,19 & & \\
\hline bPAG12 & AF020514 & 375 & 19 & & \\
\hline fPAG & AF036953 & 388 & 30 & Cat & {$[12]$} \\
\hline ePAG & L38511 & 388 & 25 & Horse & \multirow{2}{*}{ [13] } \\
\hline zPAG & AF036952 & 388 & term placenta & Zebra & \\
\hline bPAG13-16*, 17*-21 & AF192330-8 & $370-381$ & 19 & Cattle & [14] \\
\hline cPAG1-11 & AF191326-336 & $341-386$ & $45,65,87,115$ & Goat & {$[15]$} \\
\hline mPAG-like & AF240776 & 387 & 16 & Mouse & {$[16]$} \\
\hline wtdPAG1 & AY509865 & 380 & \multirow{10}{*}{$85-90$} & \multirow{10}{*}{$\begin{array}{l}\text { White- } \\
\text { tailed deer }\end{array}$} & \multirow{10}{*}{ [17] } \\
\hline wtdPAG2 & AY509866 & 376 & & & \\
\hline wtdPAG2v & AY509867 & 376 & & & \\
\hline wtdPAG3 & AY509868 & 381 & & & \\
\hline wtdPAG4 & AY509869 & 385 & & & \\
\hline wtdPAG5 & AY509870 & 385 & & & \\
\hline wtdPAG6 & AY509871 & 376 & & & \\
\hline wtdPAG7 & AY509872 & 381 & & & \\
\hline wtdPAG8 & AY509873 & 376 & & & \\
\hline wtdPAG9 & AY509874 & 258 & & & \\
\hline pPAG3 (103C) & AF315377 & 389 & \multirow{6}{*}{$13-17$} & \multirow{6}{*}{ Pigs } & \multirow{6}{*}{ [8] } \\
\hline pPAG4*(A11A) & AF272734 & 389 & & & \\
\hline pPAG5 (101C) & AY188554 & 342 & & & \\
\hline pPAG6*(113B) & AF272735 & 389 & & & \\
\hline pPAG8* (109C) & AY373029 & 342 & & & \\
\hline pPAG10*(108B) & AY775784 & 389 & & & \\
\hline
\end{tabular}

Explanation: Sequences of PAG cDNA can be accessed in the National Center for Biotechnology Information (www.ncbi.nlm.nih.gov/BLAST) under the indicated numbers (Acc. Nos.). Genes that are marked (*) code polypeptide chains of precursors with high homology to N-terminal micro-sequences of native PAG proteins, presented in Tables III and IV. 
these identified cDNA sequences represent distinct transcripts encoding unique polypeptide PAG precursors. Some eutherian species outside the Artiodactyla, comprising the Perissodactyla, Carnivora and Rodentia orders, have been shown to possess only a single PAG-like member. These include equine PAG in the horse and zebra, feline and mouse PAG-like cDNA (Tab. I). Cloning of the PAG and PAG-like gene family (bPAG, cPAG, ePAG, fPAG, mPAG, oPAG, pPAG, wtdPAG and zPAG) revealed distinct chorionic transcripts. The number of the PAG mRNA is known to vary between species and their expression can sometimes change during the course of pregnancy (Tab. I). Presumably, distinct number and pregnancy-stage dependent expression of the PAG transcripts can be associated with specific requirements of foetal development in different species.

The identification of an open reading frame (ORF) for each cloned cDNA allowed for in silico translation of the full-length polypeptide PAG precursors (Tab. I). In silico translations also permitted a comparison of the homology/identity between family members and the detection of numerous amino acid (aa) substitutions. The pre-forms of the PAG polypeptide chains are generally 375-389 aa in length, however, shorter 258-342 aa forms were also identified in various species. The PAG family has several conserved regions and shares $\sim 50 \%$ sequence identity with the pepsinogen family. One of the regions of greatest conservation among the PAGs [21] and other members of the AP superfamily $[22,23]$ is within those areas comprising the active site centre of these molecules. Catalytic activity of the AP depends on two aspartic acids located within the different active domains belonging to the amino- and carboxy-terminal lobes that, together, create the substratebinding cleft. Some of the PAG family members possess multiple aa substitutions within the catalytic site and, therefore, are predicted to be unable to function as classical proteinases [2, 6-9, 14, 15, 17]. In the pig, for example, the typical pepsinlike sequence within the catalytic domains is conserved in the pPAG2-like subfamily only (pPAG2, pPAG4, pPAG6, pPAG8 and pPAG10) [6,8]. No classical erosion of the maternal tissues occurs during porcine placentation; therefore, in silico predicted proteolytic activity of the pPAG-2 group [7,8] is likely directed toward specific substrates/targets at the placenta-uterine interface rather than a general activity that might normally have permitted erosion of maternal tissues and placental invasion. In contrast, the pPAG1-like subfamily (pPAG1, pPAG3 and pPAG5) was predicted to be potentially inactive, according to four aa substitutions: Gly $\rightarrow \mathrm{Ala}^{81}$ in domain 1, and $\mathrm{Thr} \rightarrow \mathrm{Ser}^{263}$, Thr $\rightarrow \mathrm{Ser}^{265}$, Ser $\rightarrow$ $\mathrm{Ala}^{266}$ in domain 2 [8]. Similar aa substitutions have been reported in other eutherians, e.g., Gly $\rightarrow \mathrm{Ala}^{81}$ in domain 1 of bPAG1, or Asp $\rightarrow$ Gly $^{257}$ in domain 2 of oPAG1 [2], and in several other ruminant PAG members [9,14,15,17]. Although such mutations are predicted to render the PAGs incapable of proteolytic activity, the recent identification of enzyme activity in the histo-aspartic proteinase genes (HAP I and II) and several plasmepsins from the malarial parasite (Plasmodium falciparum) does suggest that proteolytic activity may still reside in PAGs with atypical active sites $[24,25]$.

\subsection{Exon-intron structure of the PAG genes, promoters and gene number analyses}

The identification of the structural organisation of the PAG genes or their promoters was performed on the basis of identified gDNA sequences (Tab. II) and required single gene isolation by genomic bovine or porcine library screenings ( $1.2 \mathrm{kbp}$ promoter and $\sim 8 \mathrm{kbp}$ gene). 
Table IIA. Recognised structural organisation of two genes from the PAG family, with their DNA sequences that have been deposited in the GenBank database.

\begin{tabular}{llll}
\hline Gene (clone) & Accession number & gDNA sequences & Identified by \\
\hline \multirow{2}{*}{ bPAG1 (bpg2000) } & L27833 & exons 1-6 & \\
& L22834 & exons 7-8 & 26] \\
& L27832 & exon 9 & \\
& $\mathrm{U} 41421$ & exon 1 & \\
& $\mathrm{U} 41422$ & exon 2 & \\
pPAG2 (g5) & $\mathrm{U} 39199$ & exon 3, intron C, exon 4 & [27] \\
& $\mathrm{U} 41423$ & exon 5 & \\
& $\mathrm{U} 41424$ & exon 6 & \\
& $\mathrm{U} 39762$ & exon 7, intron G, exon 8 & \\
& $\mathrm{U} 39763$ & exon 9 & \\
\hline
\end{tabular}

Table IIB. Identified promoter sequences of the PAG gene family deposited in the GenBank database.

\begin{tabular}{llll}
\hline Gene & $\begin{array}{l}\text { Accession } \\
\text { number }\end{array}$ & $\begin{array}{l}\text { Length of identified } \\
\text { promoter regions (bp) }\end{array}$ & $\begin{array}{l}\text { Identified } \\
\text { by }\end{array}$ \\
\hline bPAG1 & L27833 & 1260 & {$[26]$} \\
bPAG2 & AY212886 & 955 & {$[28]$} \\
ePAG & AF061188 & 389 & {$[13]$} \\
pPAG2 & U39198 & 1204 & {$[27]$} \\
\hline
\end{tabular}

The entire exon-intron structures were identified for two PAG genes only, bovine PAG1 [26] and porcine PAG2 [27]. The gDNA sequencing of the PAG genes and comparison to the ORF of previously cloned cDNAs allowed for structural identification of 9 exons and 8 introns $(\mathrm{A}-\mathrm{H})$ in the bovine and porcine PAG genes. For example, in the pPAG2 gene, the exons are 99-200 bp long and introns contain from $85 \mathrm{bp}$ up to $\sim 1.8 \mathrm{kbp}$. The bPAG1 gene has a similar structure. However, intron $\mathrm{H}$ is $\sim 1.8 \mathrm{kbp}$ in the bPAG1 gene, but is much shorter (292 bp) in the pPAG2 gene. Exon 1 codes for signal peptides and propieces, exons 2-5 code for the $\mathrm{N}$-terminal lobe and exons 6-9 code for the C-terminal lobe of the mature PAG polypeptide.

An examination of the functional activity of PAG genes begins with the cloning and sequencing of the promoter [13,26-28]. So far, only a few promoter sequences of the PAG genes were identified and deposited in GenBank (Tab. IIB). The comparison of the PAG promoter sequences revealed that their proximal regions are similar to each other, but not to promoters of other AP or other trophoblast-expressed genes [27]. This study demonstrated $\sim 65.8 \%$ identity between pPAG2 and bPAG1 promoters, and $\sim 74 \%$ identity to $350 \mathrm{bp}$ fragment of the ePAG promoter. In addition, unique tandem repeats TCTTATCAGG in the pPAG2 promoter were found. Shorter conserved repeats (7 bp) were also found in other PAG promoters. Presently, the significance of these unique repeats remains unknown. Short tandem repeats were also found in the proximal promoter region of the alpha subunit of human chorionic gonadotrophin [29]. Thus, it can be expected that short tandem repeats, identified in sequences of trophoblastic gene promoters, may play a crucial role in placentalspecific transcription of the PAG genes. 
An activation of the PAG genes is probably specifically regulated by many transcription factors. Indeed, consensus binding sites for GATA, STAT and Ets transcription factors were identified in the PAG precursors [26,27]. Five fragments $(-1162$, $-974,-691,-357$ and -149 bp upstream of tsp - transcription start point) of the pPAG2 promoter (containing these transcription factor sequences) were cloned and examined in various transfected stable cell lines. The highest activity was found for the shortest proximal fragment $(-149 \mathrm{bp})$ of the pPAG2 promoter, when JAr or JEG3 (Human choriocarcinoma) and Rcho (Rat choriocarcinoma) were transfected. Such activity did not occur in non-trophoblastic cell lines, Cos-1 (monkey kidney), L929 (mouse adipose tissue fibroblast), but lower activity was found in CHO-K1 (Chinese hamster fibroblasts). Presumably, Ets factors can play an important role in the activation of the PAG genes. The involvement of Ets factors in the control of IFN- $\tau$ has been shown in ruminants $[30,31]$ or in specific control of human gene expression [32]. The activation of the PAG genes may also be controlled by other mechanisms or transcription factors that are indicated for cathepsin D promoter [33] or other placental promoters of hCG [34], Prl [35], Prl-like placental proteins [36, 37] and lactogens [38]. Overall, the PAG genes have structural exon-intron organisation very similar to the pepsinogen family; however, the promoter sequences are very distinct. The promoters of the PAG genes and the involvement of various transcription factors in the mechanism of the PAG gene activation within chorionic cells require future investigation.

Evidence for a multiplicity of PAG genes has come from the screening results of various cDNA libraries (Tab. I). Other studies performed with restriction endonuclease-digested cellular gDNA by Southern hybridisation also demonstrated that numerous PAG genes are likely to exist in artiodactyls [9, 26, 27, 39]. Indeed, as many as 100 PAG genes are predicted to exist in the genomes of ruminant ungulates. In the porcine genome, at least 8 pPAG2-like genes were determined. However, the number of the pPAG1-like genes is presently unknown, as well as in other eutherian species.

Recent studies of gDNA examined by PCR and autoradiographic Southern hybridisation demonstrated polymorphism of the PAG gene family, i.e. different number and length of the PAG amplicons in various species, including the pig, wild boar, cattle, sheep, goat, elk, beaver [40-43], Carnivora species [44] and European bison $(\mathrm{Eb})$ - classified as an endangered species: EN A2ce, C2a, IUCN [45, 46]. These produced gDNA amplicons suggest that some PAG genes in these species can have shortened introns $\mathrm{E}, \mathrm{G}$ and $\mathrm{H}$, which are between exons 5-6, 7-8 and 8-9, respectively. A profile of produced gDNA amplicons indicated the PAG genotypes of various domestic and wild animals. Moreover, macroscopic examination of reproductive organs of eliminated Polish Eb showed that almost $80 \%$ of bulls possess a vestigial uterus [47]. Interestingly, examination of gDNA amplicons in the Eb suggests that those Polish males with these regressive uteri present distinct PAG genotypes than the Swedish male population [46]. It is possible that inbreeding between related animals influenced the genotypes of these Polish males. Thus, presumably, the PAG gene family can be used as a novel genetic PAG marker that can be advantageous for early pre-selection of young animals what can contribute for economically effective reproduction and better conservation of endangered eutherians.

\subsection{Pregnancy-stage dependent and cell-specific mRNA expression of the PAG family}

Spatial profiles and cell-specific localisation of PAG mRNA expression in 
chorionic cells (TR, TRD) during different embryo/foetal development has been determined with numerous PAG cDNAs as probes (see Tab. I). Northern analyses revealed that PAG transcript expression starts in the TR at peri-implantation and persists in TRD until term. In ruminants, the $\mathrm{mR}$ NAs of the bovine and ovine PAG genes are detectable from 17 days post coitum (dpc) $[2,9,10,14]$ and caprine PAG mRNAs from $18 \mathrm{dpc}$ [15]. In the pig, the pPAG mRNAs is detectable by Northern hybridisation from $15 \mathrm{dpc}$ [6], but in the mare from 32 dpc [13]. However, more sensitive ribonuclease protection assays (RPA) of placental mRNA performed with antisense ovine riboprobes (cRNA) detected ovine PAG mRNA as early as 13 dpc [14]. RPA performed with porcine PAG cRNA revealed multiple pPAG2-like transcripts during early pregnancy [7]. In addition, hybridisations of pregnant endometrial samples with the PAG probes have been found to be beneficial for demonstrating TRD contamination of endometrial samples [6].

During early placenta development of several species, TR cells proliferate and differentiate into specialised giant cells. In ruminants, such cells are known as binuclear cells (BNC) that comprise approximately $20 \%$ of the TRD cell population [48-51]. Upon formation of a mature placenta, some BNC migrate from the TRD to fuse with maternal uterine epithelial cells, creating either a foetal-maternal syncytium or short-lived trinucleate cells, depending on the species [50].

Several PAG mRNAs are differentially transcribed in ruminant mononuclear (MNC) and/or BNC. Numerous PAGs are detectable at different stages of pregnancy $[2,9,10,14,51]$. Bovine PAG1 is expressed from $45 \mathrm{dpc}$ till $250 \mathrm{dpc}$, but is not expressed as early as $25 \mathrm{dpc}$ [14]. In bovine BNC, bPAG1, 3, 4, 5, 6, 7 and 9 are expressed, while bPAG2, 8, 10-13 are expressed in both MNC and BNC [14]. In sheep, oPAG1 and oPAG3-9 are transcribed in BNC, but oPAG2 is expressed throughout TRD $[9,14]$. In goats, cPAG2 has been detected only during early pregnancy (18-19 dpc) throughout TRD, cPAG8 is expressed during the entire pregnancy, but 9 distinct transcripts (cPAG1, cPAG3-7 and cPAG9-11) start expression from $45 \mathrm{dpc}$ [15]. The PAG mRNA family expression was also identified in European bison and camelids by hybridisation with the use of porcine PAG probes $[45,52]$.

In the equine placenta, the ePAG mRNA was found in the allantochorion and avascular chorion [13]. In the equine girdle cell layer, multinucleate chorionic cells (30-32 dpc) strongly proliferate [53, 54] into invasive chorionic girdle cells that are involved in the formation of maternal endometrial cups. Chorionic girdle cells produce a placental gonadotrophin (eCG), previously known as PMSG (Pregnant Mare Serum Gonadotrophin), which is detectable in maternal blood circulation after $40 \mathrm{dpc}$ [55].

In the pig, surprisingly, reverse transcription-PCR indicated that the pPAG1-like and pPAG2-like transcripts are present as early as the morula stage and 4-cell stage, respectively [56]. However, the porcine genome is activated during the 4-cell stage [57], then, on day 6-7 dpc blastocysts hatch from the zona pelucida and embryonic TR cells start intensive proliferation and morphological differentiation $[58,59]$. After implantation, an early placenta is developed by intensive growth of TRD and an expansion within maternal endometrium [49, 60, 61]. Interesting question arise about the expression of the PAG2-like family (with conserved pepsinlike sequences) within the foeto-maternal interface of the porcine placenta [6-8], which was anatomically classified as the epitheliochorial diffuse non-invasive type $[49,61]$. Moreover, porcine TR cells removed from the uterus and transplanted into an ectopic site indicated invasive properties, creating structures similar to the 
cytotrophoblast and syncytium containing an increased number of lysosomes [62]. Our in situ hybridisation (ISH) studies of the PAG mRNA expression demonstrated remodelled regions of placental surface, where endometrial cells occurring within villous folds exhibit changed shape, which is similar to conditions of digested cells [7]. In these regions, much stronger mRNA expression was determined for the pPAG2-like than for the pPAG1-like subfamily. This ISH study also revealed direct contact of TRD cells with maternal endometrial cells and several porcine binuclear cells. In addition, cultures of TR cells demonstrated their differentiation to multinucleated forms (from 3 to 9 nucleuses) that were observed in vitro only [7]. It seems that some porcine TR/TRD cells cultured in vitro (removed from inhibitory influence of maternal uterine secretion) can be more invasive as suggested previously.

\subsection{Identification of the PAG proteins}

Generally, initial cDNA cloning permits to identify full-length polypeptide precursors that can allow for sequence comparison to short micro-sequences of purified proteins, thus giving final native PAG protein identification.

Immunological identification of the PAG proteins requires various anti-PAG sera that will recognise specific antigenic determinants (epitopes) of these molecules. However, the production of polyclonal and monoclonal antisera requires species-specific antigens, thus harvesting various placental PAG proteins. Initially, anti-PAG sera were produced against semi-purified chorionic antigens, then the obtained semi-specific antisera were purified by adsorption with various bovine tissues harvested from nonpregnant animals [1]. Later, a few potential protein sources were utilised for produc- tion of placental antigens (Tab. III). As a first source, native antigens were isolated by multistep extraction from tissues, mainly ruminant placentas. As a second source, ultra-fractionated proteins from media were collected during longor short-term in vitro cultures of chorionic tissues [63, 80-82]. Removal of nonpregnancy specific immunoglobulins from anti-PAG sera was performed by use of in vitro produced adsorbents of non-pregnant animals [63, 81, 82]. As a third source, recombinant PAG proteins were produced on the basis of previously cloned cDNAs of the PAG genes $[8,13,63]$. However, recombinant PAG proteins, produced so far in bacterial systems, were useful antigens for immunological detection in some species, in which the native PAG proteins are not highly glycosylated during posttranslational modifications [13]. Several polyclonal potentially monovalent antisera were produced against singular PAG antigens, electrophoretically homogenic (identical $\mathrm{kDa}$ ). Polyclonal polyvalent antisera were produced against multiple antigens that allowed for diagnostic immunological detection of different PAG proteins during the same blotting [63]. Finally, a specificity of some anti-PAG sera was directly confirmed by beneficial immunoscreening of cDNA clones isolated from trophoblastic libraries and bounding of fusion PAG proteins $[2,63]$.

These anti-PAG sera allowed for species-specific (homologous) dot- or PAGE Western analyses and immunohistochemistry of the PAG proteins on the placental sections. In addition, relatively high homology of the PAG epitopes allowed also for heterologous (cross-species) immunological detection, very useful especially in domestic, wild and endangered animals, in which the PAG family has not been identified previously. For example, anti-porcine PAG sera were useful for identification of EbPAG proteins in placental sections 
Table III. The native PAG proteins, isolated from placental tissues of different species, in comparison to the family of PAG precursors (* see Tab. I). The theoretical molecular masses of pPAGs $(* *)$ calculated on the basis of polypeptides coded by their cDNA were compared to masses $\left(\mathrm{M}_{r}\right)$ of processed glycosylated products of the pPAG family (***). Some forms of ovine and bovine PAG protein $(* * * *)$ that $\mathrm{N}$-terminus corresponded to ovine and bovine polypeptide PAG precursors translated from their cDNA (see Tab. I).

\begin{tabular}{|c|c|c|c|c|c|}
\hline Name & $\mathrm{M}_{r} \mathrm{kDa}$ & $\begin{array}{l}\text { Ip variants } \\
\mathrm{pH}\end{array}$ & Source & $\begin{array}{l}\text { Day or month of } \\
\text { pregnancy }\end{array}$ & Identified by \\
\hline \multicolumn{6}{|c|}{ Porcine PAGs } \\
\hline pPAG-like & $35.4-72.3 * * *$ & & Medium & $15-77 \mathrm{~d}$ & {$[7,63,64]$} \\
\hline pPAG1 & $42.79 * *$ & & & & [6] \\
\hline pPAG2 & $42.57 * *$ & & & & \\
\hline pPAG3 & $43.48 * *$ & & & & \\
\hline pPAG4 & $43.58 * *$ & & mRNA & $13-17 \mathrm{~d}$ & \\
\hline pPAG5 & $37.99 * *$ & & & & \\
\hline pPAG6 & $43.59 * *$ & & & & [8] \\
\hline pPAG8 & $38.17^{* *}$ & & & & \\
\hline pPAG10 & $43.59 * *$ & & & & \\
\hline \multirow[t]{4}{*}{$\mathrm{pBP}$} & $20-25$ & $5.6-6.2$ & Medium & $10.5-12 \mathrm{~d}$ & \\
\hline & $35-50$ & 7 & & $14-16 \mathrm{~d}$ & \\
\hline & 45 & & & $18 \mathrm{~d}$ & {$[65,66]$} \\
\hline & $50-70$ & $6-7.6$ & & $25-30 \mathrm{~d}$ & \\
\hline pBP & $42.8-43.1$ & & Medium & $14-17 \mathrm{~d}$ & [67] \\
\hline pBP & 43 & 9.08 & Medium & $15 \mathrm{~d}$ & [68] \\
\hline \multicolumn{6}{|c|}{ Equine PAGs } \\
\hline ePAG & 37,41 & Activity at & Medium & $25 \mathrm{~d}$ & [13] \\
\hline R-ePAG & 41 & $\mathrm{pH} 4.5$ & & recombinant & \\
\hline \multicolumn{6}{|c|}{ Ruminant PAGs } \\
\hline bPSPB & $47-53$ & $4.0-4.4$ & Tissues & $20-45 \mathrm{~d}$ & [1] \\
\hline bPSPB & $37,48,65,85,90$ & 4.0-4.4 & Medium & $90 \mathrm{~d}$ & [69] \\
\hline & 78 & & Tissues & & \\
\hline oPSPB & $43,59,66$ & $4.06-4.65$ & Tissues & mid- and late & [70] \\
\hline oPAG1 & $47-90$ & & Medium & $15-25,100 \mathrm{~d}$ & \\
\hline R-oPAG1 & 46 & & & recombinant & {$[2,71]$} \\
\hline bPAG1 & & & Medium & $90 \mathrm{~d}$ & \\
\hline bPAG & 67 & 4.4-5.4 & Tissues & $2-6 \mathrm{~m}$ & [3] \\
\hline bPAG2 & $31-70$ & & Medium & $90 \mathrm{~d}$ & [10] \\
\hline oSBU-3 & $69,62,57$ & & Tissues & $\sim 2-3 \mathrm{~m}$ & [5] \\
\hline oPAG3/7 & $42.49 / 42.93$ & & mRNA & $100 \mathrm{~d}$ & [9] \\
\hline oPAG & $65^{* * * * *}$ & 5.54, 5.19, & & & \\
\hline oPAG & 61 & $4.06,4.0$ & & & \\
\hline oPAG & 60 & 3.56 & Medium & $100 \mathrm{~d}$ & [11] \\
\hline oPAG & 55 & $4.0-5.68$ & & & \\
\hline cPAG & $62,59,55$ & $4.9-6.2$ & Tissues & $48-69 \mathrm{~d}$ & [72] \\
\hline mPSPB & 58,31 & $4.8-6.7$ & Tissues & $?$ & [73] \\
\hline ePSPB & $57,45,31$ & $4.8-6.2$ & & & \\
\hline bubPAG & $52-77$ & & Tissues & & [74] \\
\hline zebuPAG & $51-69$ & $4.4-6.7$ & Tissues & 10-31 weeks & [75] \\
\hline oPAG & $59,57,55$ & $4.1-5.9$ & Tissues & $\geq 100 \mathrm{~d}$ & {$[76,77]$} \\
\hline oPAG & $55-66$ & $4.0-6.8$ & Tissues & $60-100 \mathrm{~d}$ & [78] \\
\hline wtdPAG & $30,50,55,60,90$ & & Tissues & $85-90 \mathrm{~d}$ & [17] \\
\hline EbPAG & $65,67,78$ & & Medium & $60-150 \mathrm{~d}$ & [45] \\
\hline bPAG6/7,1,17 & $75,66,56 * * * *$ & & Tissues & $100-180 \mathrm{~d}$ & [79] \\
\hline bPAG4,6,7,16 & $75,65,55 * * * *$ & & Medium & $24-150 \mathrm{~d}$ & [80] \\
\hline
\end{tabular}


of endangered European bison PAG (Bison bonasus L.) and camelids, including CdPAG-dromader PAG (Camelus dromedarius), CfPAG-two-humped camel (Camelus ferrus) and LpPAG-alpaca PAG (Lama pacos) [83, 84].

\subsection{Purification and $\mathrm{N}$ - terminal microsequencing of native PAG proteins}

The PAG family has been identified as a huge group of placental proteins specifically produced and secreted by the chorion of several eutherian mammals. The PAG proteins (Tab. III) were harvested on different days of pregnancy from the pig (pPAG, pBP), cattle (Bos taurus bPAG or bPSPB), sheep (oPAG, SBU3), equidae (ePAG, zebraPAG), moose and elk (mPBSB, ePBSB), white-tailed deer (wtdPAG) and European bison (EbPAG). Moreover, the PAG proteins (Tab. III) were also purified and identified in the goat (cPAG), zebu (Bos indicus - zebuPAG) and buffalo (Buffalo bubalis - bubPAG). Initial heterologous and later homologous immunodetection of the PAG proteins demonstrated a high diversity of secretory forms and pregnancy-stage dependent spatial chorionic expression. Purified PAGs possess a variety of molecular masses (varying from 30 to $90 \mathrm{kDa}$ ) and electrostatic properties (Ip; 4.0-9.08).

The PAG proteins contain some relatively similar epitopes that allowed for cross-species immunodetection. Relatively high homology of the PAG proteins in each species caused extreme difficulties during isolation and purification of singular forms of the PAG proteins in various mammals. Because of these identification difficulties, several purified PAG proteins were initially characterised by biochemical procedures and Western blotting (Tab. III), but only a small number of them were characterised by microsequencing of the $\mathrm{N}$-terminal ends (Tab. IV).
These N-terminal micro-sequences of native PAG proteins were identical or very similar to the sequences of the polypeptide PAG precursors coded by cloned cDNAs in various animals (Tab. IV). For, example, in the pig, the sequence of native pBP43 protein [68] was similar, but not identical, to the sequences of the pPAG2, $4,6,8$ and 10 polypeptide precursors [6, 8]. In sheep, oPAG65 protein revealed a similar micro-sequence to the sequences of two distinct precursors, oPAG3 and oPAG7 [9, 11]. Moreover, the N-terminus of some lately identified native oPAG proteins $(55-60 \mathrm{kDa})$ revealed high homology to the sequences of the polypeptide oPAG1, 4 and 6 precursors [76-78].

All purified native PAG protein identification provides contributive data about placental proteomes of the examined animals. The exemplary comparisons demonstrate very high diversity and multiplicity of the PAG family. This diversity of the PAG proteins is the result of the aforementioned heterogeneity of the PAG gene family. Thus, complete identification of the entire PAG family requires several chorionic protein purifications, examinations of their multiple isoforms, and cloning of cDNA that code polypeptide PAG precursors.

\subsection{Activation of polypeptide PAG precursors}

In mammals, the most important stage in the activation process of various enzymatic proteins is the transformation of their zymogens (polypeptide precursors) to mature secretory forms. The post-translational activation of the PAG is probably similar to that of other members of the AP family. The above mentioned comparison of $\mathrm{N}$-terminal micro-sequences and in silico analyses (Tab. IV) revealed that the PAGs precursors are specifically catalytically activated. Primarily, the pre-pro-polypeptide 
Table IV. The $\mathrm{NH}_{2}$-terminal micro-sequences of the native PAG proteins $(\mathrm{kDa})$ isolated from the placenta of different species in comparison to PAG precursors and rabbit pepsinogen $\mathrm{F}$ sequences (*-coded by their cDNA). The sequences of porcine PAG2, 4, 6, 8, 10, ovine PAG1, 4, 6 and oPAG3/oPAG7 precursors $(* *)$ corresponded to native proteins $(* * *)$ of $\mathrm{pBP}(43)$ and several oPAGs. The potential sites of N-glycosylation $(\mathrm{N}-\mathrm{x}-\mathrm{T} / \mathrm{S})$ of PAG precursors corresponded to empty cycles during micro-sequencing (marked by ?) of native PAG proteins. Conserved fragments are boxed (consensus), possible sites of propeptide cleavage in precursors are marked $(\downarrow)$, gaps $(-)$ were inserted for maximal sequences alignment and identical amino acids of r-pepsinogen $\mathrm{F}$ and pPAG2-like precursors are in bold letters.

\begin{tabular}{|c|c|c|c|c|c|}
\hline \multirow{2}{*}{ Name (kDa) } & \multicolumn{4}{|c|}{ Micro-sequences } & \multirow{2}{*}{$\begin{array}{l}\text { Identified } \\
\text { by }\end{array}$} \\
\hline & \multicolumn{4}{|c|}{ consensus } & \\
\hline pPAG1* & $\mathrm{KF}$ & GLKGSL CSPKISCL & RLWN & YLDMVYVGNITIGTP & {$[6]$} \\
\hline pPAG2*,** & NL & LSKNSS HVQKFSYQ & PLRN & YLDMVYVGNISIGTP & \\
\hline pPAG3/5* & $\mathrm{KF}$ & GLKGSL CSPKISCL & RLWN & YLDMVYVGNITIGTP & {$[8]$} \\
\hline pPAG4/6/8/10*,** & NL & LSKNSS HVQKFSYQ & PLRN & YLDMVYVGNISIGTP & \\
\hline $\mathrm{pBP}(43) * * *$ & & LSK? ?SS HVQKFSYQ & PLRN & YLDMVY $\underline{?} \mathrm{G}$ & {$[68]$} \\
\hline rPepsinogen $\mathrm{F}^{*}$ & TY & KLLSGQ QDPDVSFE & PLRN & YLDLAYIGIISIGTP & {$[22]$} \\
\hline ePAG* & $\mathrm{TH}$ & KLLHKH ADSGVAFE & PMRN & YLDIAYMGIISVGTP & [13] \\
\hline bPAG1* & YS & LSQISF RGSNLTTH & PLRN & IKDLVYMGNITIGTP & {$[2]$} \\
\hline oPAG1* & & 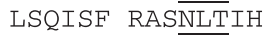 & PLRN & IMDMLYVGNITIGTP & \\
\hline bPAG(67) & & RGH? $\underline{\text { LTFG }}$ & PLRN & FLDLVYMGEFT? $\underline{\text { KDE }}$ & [3] \\
\hline bPAG2* & YR & LSKN-- -DSKITIH & PLRN & YLDTAYVGNITIGTP & [10] \\
\hline zebuPAG(67) & & RGS?्थTTH & PLRN & IKDLVYMG & [75] \\
\hline oSBU-3(69) & & QGS?्?VTIL & PLRN & MKDIFYVG? ITIDTP & {$[5]$} \\
\hline oSBU-3(62) & & 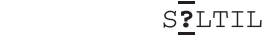 & PLRN & MㅁIFYRG疋ITIGGP & \\
\hline oSBU-3(57) & & $-I \underline{?}$ & PLRN & 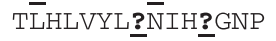 & \\
\hline oPAG $1 *, * *$ & & LSQISF RASNLTIH & PLRN & IMDMLYVGNITIGTP & [9] \\
\hline oPAG4*,** & & LPQISF RGSNLIIH & PLRN & IRDTFYVGNITIGTP & \\
\hline oPAG3/7*,** & & LPQISF RDSNVTIL & PLRN & MKDIFYVGNITIGTP & \\
\hline oPAG6*,** & & LSQISF RGSNLTIH & PLRN & TKDLVYLGNITIGTP & \\
\hline oPAG $(65)^{* * *}$ & & RDS? VTIL & PLRN & MKDIFYVG? & {$[11]$} \\
\hline oPAG(61) & & RGS? L? IH & PLRN & VKDVVYL? $\overline{\mathrm{G}}$ & \\
\hline oPAG(60) & & RGS鸟? RIH & PLRN & $\mathrm{HRD}$ & \\
\hline oPAG(55) & & SQI? LTVS & $\mathrm{NL}$ & & \\
\hline oPAG(59) & & RGSNLTIH & PLRN & IRD & {$[76,77]$} \\
\hline oPAG(57) & & ISSRVSNLTIH & PLRN & IMDML & \\
\hline oPAG(55) & & RGS?्LTIL & PLRN & MRDIVY & \\
\hline oPAG(66a) & & RDSNVTIL & PLRN & MKD & {$[78]$} \\
\hline oPAG(66b) & & RASNLTIH & $\mathrm{PL}$ & & \\
\hline oPAG(61) & & RGSNLTIH & PLRN & TNDIDY & \\
\hline oPAG $(60)^{* * *}$ & & RGSNLTIH & PLRN & TKDRVYIG & \\
\hline oPAG $(59) * * *$ & & RGSNLTIH & PLRN & IKDLVYLGNMGIG & \\
\hline oPAG(58a)*** & & RGSNLTIH & PLRN & TKDLVYLG & \\
\hline oPAG $(58 \mathrm{~b})^{* * *}$ & & RGSNLIIH & PLRN & IRDTFYVGNIT & \\
\hline oPAG $(55)^{* * *}$ & & RVSNLTIH & PLRN & IIDLRYVG & \\
\hline cPAG(62) & & RDS?्?VTIV & PLRN & MRDIVYVG? ITIGTP & {$[72]$} \\
\hline cPAG(59) & & RGS官LTTL & PLRN & IMDMLHMG'י̄ITIGTP & \\
\hline cPAG(55) & & ISS PVS疋LTH & PLRN & IMDMLYVG疋ITI & \\
\hline
\end{tabular}


chains of the PAGs precursors are degraded by approximately $1.6 \mathrm{kDa}(15$ aa signal peptide removal) and later by a 4-5 kDa decrease, caused by the removal of the pro-peptide, which varies in length somewhat across the family (38 aa in ruminants, 37 aa in pigs or 33 aa in horses) [2, 6-9, 13-15]. However, so far, an auto-activation (inhibited by pepstatin A) has only been indicated for the recombinant PAG-like proteins in mice and horses $[13,16]$. Presumably, the autoregulation of the placental proteins is associated with morphological and functional differentiation of the chorionic cells during placenta development.

It seems that in N-terminal ends of ruminant $\mathrm{PAG}$ native proteins the sequence of 3 amino acids, $\downarrow \underline{R}-\mathrm{D} / \mathrm{G}-\underline{\mathrm{S}}$ dominates mainly (Tab. IV). However, similar sequence R-D/G-S does not occur in pepsinogen precursors and in porcine and equine PAG precursors. The N-terminus of mature secretory porcine PAG2-like proteins begins with sequence $\downarrow$ LSK $[7,8,68]$, or with sequence $\downarrow$ THK in the equine PAG [13]. In addition, almost all identified micro-sequences of ruminant PAG proteins contain conserved sequence PLRN (Tab. IV). This sequence is changed to PMRN in the ePAG precursor [13], or it is modified to RLWN in the pPAG1, 3 and 5 precursors $[6, \overline{8}]$. The physiological significance of these changes is presently unknown and requires future investigation.

\subsection{Glyco-diversity of the PAG family}

Generally it is known that various intracellular and membrane glyco-conjugates are involved in several important processes: cell-cell adhesion, masking of surface antigens during embryonic development and removal of glycoproteins from blood circulation. The diversity of glycoprotein receptors, variable content, secretion profile and yield of glycosylation play important roles in the regulation of foetomaternal interactions during early human pregnancy [85]. In the pig, a heterogenic group of glucosaminoglycans (GAGs) are produced by uterine tissues that influence several changes in secretion profiles required for morphological differentiation of endometrial epithelium and successful implantation [86]. Moreover, culture medium supplementation with GAGs (heparin and hyaluronic acid) affected embryonic GAG receptors and generally improved the developmental competence of porcine pre-implantation embryos in terms of increased blastocyst formation rate or total trophoblast cell number [87].

The native PAG proteins, either purified from placental tissues or produced in vitro by chorionic explants and released into media, are characterised by extremely high $\mathrm{Mr}$ in comparison to the predicted masses of the polypeptide PAG precursors, as calculated from the cloned cDNA (Tab. III). Several PAG proteins possess masses of $\sim 70 \mathrm{kDa}$, approximately two times larger than their calculated masses $(42.5 \mathrm{kDa})$. First evidence of high glycosylation was found during sequencing of cloned cDNA of the PAG genes. Various numbers of potential $\mathrm{N}$-glycosylation sites of asparagine $(\mathrm{N}-\mathrm{x}-\mathrm{S} / \mathrm{T}$ in precursors presented in Tab. IV) were identified, at least three in porcine PAG precursors $[6$, 8, 64], up to seven glycosylation sites in ruminant PAGs $[9,15]$, and only one glycosylation site in ePAG, which is not present in the zebra PAG precursor [13]. More evidence for $\mathrm{N}$-glycodiversity come from N-terminal microsequencing of purified PAG proteins (marked by "?" in Tab. IV). In sheep and cattle, only some of these N-glycosylation sites are identical in the polypeptide PAG precursors and in the PAG proteins. In the pig, a second empty cycle (?) during microsequencing of the pBP ( $4 \overline{3} \mathrm{kDa})$ protein [68], did not confirm $\mathrm{N}-\mathrm{x}-\mathrm{S} / \mathrm{T}$ site in the pPAG2-like precursors $\overline{(\text { Tab. IV) }}$, in which Val was identified $[6,8]$. 
This suggests additional expression products within the pPAG2-like subfamily that dominate during early pregnancy in this species. The post-translational modifications of native PAG proteins i.e. specific glycosylation within the placenta lead to a large variability of the PAG proteins purified and identified from placental extracts or culture media.

The post-translational glycosylation of the PAG proteins were identified in several domestic and wild animals during various stages of pregnancy (see Tab. III for gestation stage). In these studies, the PAG proteins were enzymatically deglycosylated by glycopeptidase $\mathrm{F}$ treatment. In the pig, the oligosaccharide content is an average $9.66 \%$ throughout pregnancy, but can be from 7 to $25 \%$ during implantation [64]. In cattle, the content of oligosaccharides can account for $10 \%$ of total mass of native bPAG (67 kDa) proteins [3]. However, other studies indicated that the content of oligosaccharides can be much higher (up to $49 \%$ ), because the mass of three partially purified bPAG proteins $(75,66$ and $56 \mathrm{kDa})$ were reduced to approximately $37 \mathrm{kDa}[79,88]$. Also, native $67 \mathrm{kDa}$ and recombinant $54 / 52 \mathrm{kDa}$ bPAG proteins were also reduced to $37 \mathrm{kDa}$ [89]. In wild ruminants, the PAG/PSPB proteins contain 3.15 and $4.98 \%$ of oligosaccharides in the moose and the elk, respectively [73]. In sheep, the glycosylation of SBU3 proteins, belonging to the oPAG family, may increase the mass of polypeptides by $18 \%$ [5]. During this study, the content of various monosaccharides was also estimated: fucose $0.34 \%$, mannose $1.81 \%$, galactose $1.94 \%$, glucose $0.61 \%, \mathrm{~N}$-acetylgalactosamine $3.62 \%, \mathrm{~N}$ acetylglucosamine $5.26 \%$ and sialic acid $4.25 \%$. Moreover, some experiments performed with an inhibitor of glycosylation (tunicamycin) revealed decreased forms (by $8-10 \mathrm{kDa}$ ) of the oPAG proteins [71]. The oPAG/SBU3 proteins were examined for structures of these oligosaccharides and multi-antennae chains (bi-, tri- and tetraantennae oligosaccharides) were found in this species [5]. These structures are probably unique for the glycosylation occurring during post-translational modification of the PAG proteins within the placenta.

\subsection{Pregnancy diagnostic PAG tests}

The highest embryonic mortality occurs during maternal recognition of pregnancy and during early implantation in different species [90]. In ruminants, over $35 \%$ of foetuses are lost during the first trimester of pregnancy [91]. In the pig, embryonic mortality is comparable and can reach 30-40\% [92]. Such losses have been attributed to asynchronic development of conceptuses that are created during the $96 \mathrm{~h}$ ovulation period [92]. Embryonic mortality decreases during early placentation, before $30 \mathrm{dpc}$, and is the lowest during middle and late pregnancy [93]. These periods of greatest embryonic mortality are correlated with intensive proliferation of trophoblastic cells. Binucleate chorionic cells migrate in the direction of maternal uterine vessels, where granules containing the PAG proteins are released $[3,94]$.

Purified native or recombinant PAG proteins and specific anti-PAG sera has led to the establishment of several diagnostic tests of pregnancy based on the detection of PAGs in maternal blood plasma or serum. The major significance of PAG assays in ruminants, similar to urine or plasma hCG tests in primates, is the direct identification of a placental product present in the maternal system that can be used as a marker of a viable pregnancy. In ruminants, numerous forms of the PAG proteins are detectable in peripheral maternal blood during the third week of pregnancy. The presence of PAGs can be measured by radioimmunologic (RIA) and immunoenzymatic (ELISA) tests. These PAG tests allow for early 
pregnancy diagnoses in domestic cattle [69,80,91,95-98], sheep [70,99-104] and goats $[105,106]$. Moreover, heterologous PAG tests were also useful for pregnancy diagnoses in wild ruminants, i.e. wood bison [107], moose [108], rocky mountain elk [109], white-tailed deer [110,111], mule deer [111], red deer [112], sika deer [113], fallow deer $[114,115]$, mountain goat [116] and Alpine goats [117-119]. The measurement of PAG protein concentrations in maternal blood or milk of ruminants allow for 76.6-100\% accuracy rates for early pregnancy diagnoses [120, 121] and provide an alternative method to ultrasonography for determining late embryonic mortality [96, 122].

The concentration of circulating PAGs depends on the number of well-being embryos/foetuses, and is higher in females with multiple than single pregnancies, according to the greater mass of the chorionic membranes in animals bearing twins $[4,70$, $98,99,117,118]$. The secretion of PAGs can also differ based on the sex and breed of the foetus. Higher PAG concentration was determined in cows with male foetuses of the same breed, however in Hereford cows with transferred Holstein embryos the PAG concentration was higher in mothers with female foetuses [97].

A profile of circulating PAG is also pregnancy-stage dependent. In cattle and goats, the PAG concentration increases as pregnancy progresses $[80,97,119]$. In sheep, the concentration pattern of the PAGs is biphasic [99, 102, 104], increases (300-400 ng. $\mathrm{mL}^{-1}$ ) during the second month of pregnancy, when chorionic cells have intensively proliferated and the placenta was formed. During mid-pregnancy, the concentration of ovine PAGs is somewhat decreased $\left(<100 \mathrm{ng} \cdot \mathrm{mL}^{-1}\right)$, but increases again towards term, $300 \mathrm{ng} . \mathrm{mL}^{-1}$ in Merino, 600 ng. $\mathrm{mL}^{-1}$ in Churra [102] and over $1000 \mathrm{ng} . \mathrm{mL}^{-1}$ during multiple pregnancies in Berrichone breeds [99].
Thus, it can be expected that the PAG protein families are more diverged in various breeds of different animals.

\section{POTENTIAL FUNCTION(S) OF THE PAG FAMILY}

Bovine PAG proteins were hypothesised as local immunosupressive factors that can be involved in the maintenance of the histoincompatible foeto-maternal unit [123]. Diverse localisation of two PAG groups suggests different possible functions [51]. One ancient PAG group, mainly expressed at the foeto-maternal interface (microvillar junction), can be involved in binding the surfaces together and/or in the establishment of an immunological barrier. The expression of the more recently evolved second PAG group is restricted to bovine BNCs located mainly in the maternal villi of the placentomes, thus they are ideally positioned to modulate the maternal immune system [51].

High homology of the residues within domains creating an active site (substratebinding cleft) of the PAG proteins are probably important for some function of these molecules. Only a few studies suggested protein-protein interactions or some targets/receptors of the PAG/PSPB molecules. In cyclic ruminants, endometrial explants (harvested on day 16) perfused with bPSPB alone or together with oxytocin increased the secretion of $\mathrm{PGF}_{2 \alpha}$ and $\mathrm{PGE}_{2}$ [124]. In addition, luteal cells treated with bPSPB increased production of $\mathrm{PGF}_{2 \alpha}$ and $\mathrm{PGE}_{2}$, without influence on progesterone $\left(\mathrm{P}_{4}\right)$ secretion [125]. In contrast, another study demonstrated that PSPB treatment increased $\mathrm{P}_{4}$ secretion by mixed small and large (days 17-18) bovine luteal cells [126]. The regulation of PGE secretion by ovine CL (88-90 dpc) may also be via PSPB, which increased PGE and $\mathrm{P}_{4}$ secretion [127]. During in vivo studies, plasma PSPB and 
oestradiol $17 \beta$ concentration was increased in ovariectomised (OVX) pregnant ewes $(90 \mathrm{dpc})$, but oestradiol increased before PSPB [128]. In vitro studies with placenta slices collected seven days later from the same OVX ewes revealed that secretion of $\mathrm{P}_{4}, \mathrm{PGE}$, oestradiol $17 \beta$ and PSPB was increased by 2.7-, 3.6-, 2.2- and 2.4fold, respectively, when compared to secretion by placenta slices of intact pregnant ewes [128]. The authors concluded that oestrogens regulate chorionic secretion of PSPB, which can influence placental secretion of $\mathrm{PGE}_{2}$ that affect placental secretion of $\mathrm{P}_{4}$ during mid-pregnancy in sheep. Moreover, endometrial (END) secretion in vitro of $\mathrm{PGE}_{2}$ was increased by PSPB treatment (on 60 and $90 \mathrm{dpc}$ ), thus the authors concluded that $\mathrm{PGE}_{2}$ secretion by caruncular/placental tissues after $50 \mathrm{dpc}$ appears to be regulated by PSPB, not LH [129]. In another study, END from day 14 non-pregnant cows treated with the PSPB/PAG proteins increases secretion of $8 \mathrm{kDa}$ uterine protein that was identified to be an alpha chemokine - granulocyte chemotactic protein-2 (GCP-2) by Western blotting [130]. Possibly, starting expression of trophoblastic PSPB/PAG can stimulate the GCP-2 during implantation time. However, during this time the uterine GCP-2 is also induced by short-time expression of trophoblastic antiluteolytic IFN- $\tau$ in ruminants [131].

In the pig, secretory pPAG proteins produced in vitro competed with ${ }^{125} \mathrm{I}-\mathrm{hCG}$ in a concentration-dependent and pregnancy stage-dependent manner for binding by luteal (CL) and uterine gonadotropin receptors (myometrial and endometrial) of cyclic and pregnant pigs $[82,132,133]$. These studies suggest that the pPAG proteins may play a role as potential antiluteolytic or luteoprotective chorionic-origin signalling ligands mainly during the periimplantation period. The PAG proteins may also act locally within the uterus and influence placenta development. Recently obtained ligand-target/receptor binding results with the use of ${ }^{125} \mathrm{I}$-hCG suggest that the identification of gonadal and extragonadal receptors require further studies with the use of purified and ${ }^{125}$ I-labelled PAG standards - as the positive control chorionic ligands (commercially not-available at the present).

\section{CONCLUSIONS}

The recent cloning of the PAG genes has increased our knowledge of similarities and differences in the genomes and placental transcriptomes of eutherian animals. Presumably, the identification of the entire PAG protein family, coded by distinct genes in particular species, will allow for preparation of various commercial diagnostic tests: protein markers - for embryonic mortality, and genetic markers - for early evaluation of young animals for their effective reproduction. Moreover, the inclusion of PAG probes in microarray platforms may provide a means to ascertain selective genetic tests, based on PAG polymorphisms between individuals and to correlate different PAG genotypes to reproductive performance. In addition, the availability of numerous PAG cDNAs provides an important source of templates required for recombinant PAG protein production. Each cloned cDNA also permits an accurate guide for the identification of the structural organisation of PAG genes and their promoters.

The function(s) of multiple PAG protein family (active and inactive as proteinases) may be complex and combined with specific expression during pregnancy stages. Some PAG members can affect maternal recognition of pregnancy, adhesion of trophoblast and implantation, while other PAG members may be involved in remodelling of the foeto-maternal unit during placenta development in various mammalian species. 


\section{ACKNOWLEDGEMENTS}

This paper was supported by the State Committee for Scientific Research (PBZ-KBN 084/P06/02/3.4a) and the University of Warmia and Mazury (UWM528-0206.0805), Poland. The authors thank Jonathan Green (University of Missouri-Columbia, USA) for his helpful suggestions and comments regarding the manuscript.

\section{REFERENCES}

[1] Butler JE, Hamilton WC, Sasser RG, Ruder CA, Hass GM, Wiliams RJ. Detection and partial characterization of two bovine pregnancy-associated proteins. Biol Reprod 1982, 26: 925-933.

[2] Xie S, Low BG, Nagel RJ, Kramer KK, Anthony RV, Zoli AP, Beckers JF, Roberts RM. Identification of the major pregnancyspecific antigens of cattle and sheep as inactive members of the aspartic proteinase family. Proc Natl Acad Sci USA 1991, 88: 10247-10251.

[3] Zoli AP, Beckers JF, Woutters-Ballman P, Falmagne P, Ectors F. Purification and characterization of a bovine pregnancyassociated glycoprotein. Biol Reprod 1991, 45: $1-10$.

[4] Mialon MM, Camous S, Renand G, Martal J, Menissier F. Peripheral concentrations of a $60-\mathrm{kDa}$ pregnancy serum protein during gestation and after calving and in relationship to embryonic mortality in cattle. Reprod Nutr Dev 1993, 33: 269-282.

[5] Atkinson YH, Gogolin-Ewens KJ, Hounsell EF, Davies MJ, Brandon MR, Seamark RF. Characterization of placentation-specific binucleate cell glycoproteins possessing a novel carbohydrate. J Biol Chem 1993, 268: 26679-26685.

[6] Szafranska B, Xie S, Green J, Roberts RM. Porcine Pregnancy-Associated Glycoproteins: new members of the aspartic proteinase gene family expressed in the trophectoderm. Biol Reprod 1995, 53: 21-28.

[7] Szafranska B, Panasiewicz G. The placental expression of the porcine pregnancyassociated glycoprotein (pPAG) gene family examined in situ and in vitro. Anim Reprod Sci 2002, 72: 95-113.

[8] Panasiewicz G, Majewska M, Szafranska B. Trophoblastic cDNA cloning of porcine
Pregnancy-Associated Glycoprotein genes (pPAG) and in silico analysis of coded polypeptide precursors. Reprod Biol 2004, 4: 131-141.

[9] Xie S, Green J, Bixby JB, Szafranska B, Demartini JC, Hecht S, Roberts RM. The diversity and evolutionary relationships of the pregnancy-associated glycoproteins, an aspartic proteinase subfamily consisting of many trophoblast-expressed genes. Proc Natl Acad Sci USA 1997, 94: 12809-12816.

[10] Xie S, Low BG, Nagel RJ, Beckers JF, Roberts RM. A novel glycoprotein of the aspartic proteinase gene family expressed in bovine placental trophectoderm. Biol Reprod 1994, 51: 1145-1153.

[11] Xie S, Green J, Bao B, Beckers JF, Valdez KE, Hakami L, Roberts RM. Multiple pregnancy-associated glycoproteins are secreted by day 100 ovine placental tissue. Biol Reprod 1997, 57: 1384-1393.

[12] Gan X, Xie S, Green J, Roberts RM Identification of transcripts for pregnancyassociated glycoprotein (PAG) in Carnivora and Perissodactyla. Biol Reprod 1997, 56: 190.

[13] Green J, Xie S, Szafranska B, Newman A, Gan X, McDowell K, Roberts RM. Identification of a new aspartic proteinase expressed by the outer chorionic cell layer of the equine placenta. Biol Reprod 1999, 60: 1069-1077.

[14] Green JA, Xie S, Quan X, Bao B, Gan X, Mathialagan N, Beckers JF, Roberts RM. Pregnancy-associated bovine and ovine glycoproteins exhibit spatially and temporally distinct expression patterns during pregnancy. Biol Reprod 2000, 62: 1624-1631.

[15] Garbayo JM, Green J, Manikkam M, Beckers JF, Kiesling DO, Ealy AD, Roberts RM. Caprine Pregnancy-Associated Glycoproteins (PAGs): their cloning, expression and evolutionary relationship to other PAG. Mol Reprod Dev 2000, 57: 311-322.

[16] Chen X, Rosenfeld CS, Roberts RM, Green JA. An aspartic proteinase expressed in the yolk sac and neonatal stomach of the mouse. Biol Reprod 2001, 65: 1092-1101.

[17] Vawter GA, Parks TE, Killian G, Ealy $\mathrm{AD}$, Green JA. Cloning and preliminary characterization of Pregnancy-Associated Glycoproteins expressed in the placenta of white-tailed deer. Biol Reprod 2004, 70: 153. 
[18] Roberts RM, Xie S, Mathialagan N Maternal recognition of pregnancy. Biol Reprod 1996, 54: 294-302.

[19] Hughes AL, Green JA, Garbayo JM, Roberts RM. Adaptive diversification within a large family of recently duplicated, placentally expressed genes. Proc Natl Acad Sci USA 2000, 97: 3319-3323.

[20] Hughes AL, Green JA, Piontkivska H, Roberts RM. Aspartic proteinase phylogeny and the origin of pregnancyassociated glycoproteins. Mol Biol Evol 2003, 20: 1940-1945.

[21] Guruprasad K, Blundell TL, Xie S, Green J, Szafranska B, Nagel RJ, McDowell K, Baker CB, Roberts RM. Comparative modelling and analysis of amino acid substitutions suggests that the family of pregnancy associated glycoproteins includes both active and inactive aspartic proteinases. Protein Engineer 1996, 9: 849-856.

[22] Kageyama T, Tanabe K, Koiwai O Structure and development of rabbit pepsinogens: stage-specific zymogens, nucleotide sequences of cDNAs, molecular evolution, and expression during development. J Biol Chem 1990, 265: 17031-17038.

[23] Kageyama T, Ichinose M, TsukadaKato S, Omata M, Narita Y, Moriyama A, Yonezawa S. Molecular cloning of neonate/infant-specific pepsinogens from rat stomach mucosa and their expressional change during development. Biochem Biophys Res Co 2000, 267: 806-812.

[24] Banerjee R, Liu J, Beatty W, Pelosof L, Klemba M, Goldberg DE. Four plasmepsins are active in the Plasmodium falciparum food vacuole, including a protease with an active-site histidine. Proc Natl Acad Sci USA 2002, 99: 990-995.

[25] Berry C, Humphreys MJ, Matharu P, Granger R, Horrocks P, Moon RP, Certa U, Ridley RG, Bur D, Kay J. A distinct member of the aspartic proteinase gene family from the human malaria parasite Plasmodium falciparum. FEBS Letters 1999, 447: 149-154.

[26] Xie S, Green J, Beckers JF, Roberts RM. The gene encoding bovine pregnancyassociated glycoprotein-1, an inactive member of the aspartic proteinase family. Gene 1995, 159: 193-197.

[27] Szafranska B, Miura R, Ghosh D, Ezashi T, Xie S, Roberts RM, Green J. Gene for porcine Pregnancy-Associated Glycoprotein 2 (pPAG2): its structural organi- zation and analysis of its promoter. Mol Reprod Dev 2001, 60: 137-146.

[28] Telugu BP, Ghosh D, Xie S, Roberts RM, Green JA. The gene for bovine pregnancyassociated glycoprotein 2 in structurally similar to aspartic proteinases, but possesses unique sequences in its promoter region. Biol Reprod Special Issues 2004, 181-182.

[29] Nilson JH, Bokar JA, Clay CM, Farmerie TA, Fenstermaker RA, Hamernik DL, Keri RA. Different combinations of regulatory elements may explain why placentaspecific expression of the glycoprotein hormone alpha-subunit gene occurs only in primates and horses. Biol Reprod 1991, 44: 231-237.

[30] Ezashi T, Early AD, Ostrowski MC, Roberts RM. Control of interferon- $\tau$ gene expression by Ets-2. Proc Natl Acad Sci USA 1998, 95: 7882-7887.

[31] Leaman DW, Cross JC, Roberts RM Multiple regulatory elements are required to direct trophoblast interferon gene expression in choriocarcinoma cells and trophectoderm. Mol Endocrinol 1994, 8: 456-468.

[32] Kilpatrick LM, Kola I, Salamonsen LA Transcription factors Ets1, Ets2, and Elf1 exhibits differential localization in human endometrium across the menstrual cycle and alternate isoforms in cultured endometrial cells. Biol Reprod 1999, 61: 120-126.

[33] Cavailles V, Augereau P, Rochefort H Cathepsin D gene is controlled by a mixed promoter, and estrogens stimulate only TATA-dependent transcription in breast cancer cells. Proc Natl Acad Sci USA 1993, 90: 203-207.

[34] Miller-Lindholm AK, Bedows E, Bartels CF, Ramey J, Maclin V, Ruddon RW. A naturally occurring genetic variant in the human chorionic gonadotropin- $\beta$ gene 5 is assembly inefficient. Endocrinol 1999, 140(8): 3496-3506.

[35] Jacob KK, Stanley FM. CCAAT/enhancerbinding protein $\alpha$ is a physiological regulator of prolactin gene expression. Endocrinol 1999, 140: 4542-4550.

[36] Dai G, Wolfe MW, Soares MJ. Distinct regulatory regions from the prolactin-like protein $\mathrm{C}$ variant promoter direct trophoblast giant cell versus spongiotrophoblast cellspecific expression. Endocrinol 1999, 140: 4691-4698

[37] Orwig KE, Dai G, Rasmussen CA, Soares MJ. Decidual/trophoblast prolactin-related protein: characterization of gene structure 
and cell-specific expression. Endocrinol 1997, 138: 2491-2500.

[38] Lin J, Linzer DI. Identification of trophoblast-specific regulatory elements in the mouse placental lactogen II gene. Mol Endocrinol 1998, 12: 418-427.

[39] Green JA, Xie S, Roberts RM. Pepsinrelated molecules secreted by trophoblast. Rev Reprod 1998, 3: 62-69.

[40] Borowczyk E, Szafranska B, Panasiewicz G, Gizejewski Z. Analysis of the Pregnancy-Associated Glycoprotein gene family (PAGs): verifying length polymorphism of PCR-amplified fragments with various genomic templates of domestic ruminant and equine Eutherian species. In 36th Annual Meeting of SSR, Cincinnati, USA, Biol Reprod 2003, 68: 248.

[41] Szafranska B, Panasiewicz G, Wacşawik A. Length polymorphism of PCR amplified genomic fragments of the PregnancyAssociated Glycoprotein (PAG) gene family in the pig and some other domestic and wild mammals. J Appl Genet 2001, 42: 335-349.

[42] Szafranska B, Panasiewicz G, Borowczyk E, Dabrowski M, Gizejewski Z. PregnancyAssociated Glycoprotein gene family as a potential genetic marker in ungulate species: pigs, domestic or wild ruminants (Bison bonasus L., Cervus elaphus) and beaver (Castor fiber L.). XXVth International Congress of the International Union of Game Biologists IUGB Wildlife Management in the 21st Century, Lemesos, Cyprus, 2001, S2: 158.

[43] Szafranska B, Kuber K, Panasiewicz G, Majewska M, Gizejewski Z, Zalewski K. Three useful genomic DNA templates of European/American bisons (B. bonasus L., B. bison), red/roe deer (Cervus elaphus, Capreolus capreolus) and wild pig (Sus scrofa L.) for Pregnancy-Associated Glycoprotein gene family (PAG) examination. BASE 2004, 8: 64-65.

[44] Panasiewicz G, Majewska M, Cegiełka A, Gizejewski Z, Zalewski K, Krzywinski A, Szafranska B. Application of porcine Pregnancy-Associated Glycoprotein gene family (PAG) for identification of novel PAG-like gene amplicons in diverse Melinae, Mustelidae and Canidae taxons. In: XXVIIth Congress of the International Union of Game Biologists, Book of Extended Abstracts, ISBN: 3-88412-431-5, 2005, pp 244-245.

[45] Szafranska B, Panasiewicz G, Dabrowski M, Majewska M, Gizejewski Z, Beckers
JF. Chorionic mRNA expression and N-glycodiversity of Pregnancy-Associated Glycoprotein family (PAG) of the European bison (Bison bonasus). Anim Reprod Sci 2005, 88: 225-243.

[46] Szafranska B, Panasiewicz G, Majewska M, Dajnowiec J, Kuber K, Bociek K, Gizejewski Z, Goczkowski M. Amplicon-polymorphism of the PregnancyAssociated Glycoprotein gene family (PAG) examined in the European bison: the Swedish population and bulls with regressive uterus from Poland. In: XXVIIth Congress of the International Union of Game Biologists, Book of Extended Abstracts, ISBN: 3-88412-431-5, 2005, pp 246-248.

[47] Gizejewski Z, Bierla J, Söderquist L, Rodriguez-Martinez $\mathrm{H}$, Ekwall $\mathrm{H}$. Preliminary results of evaluation of European bison (Bison bonasus L.) semen collected post mortem. In: Proc Conf "European Bison Conservation", Bialowieza, Poland, 2004, pp 48-49.

[48] Hoffman LH, Wooding FBP. Giant and binucleate trophoblast cells of mammals. J Exp Zool 1993, 266: 559-577.

[49] King GJ. Comparative placentation in ungulates. J Exp Zool 1993, 266: 588-602.

[50] Wooding FBP. Current topic: the synepitheliochorial placenta of ruminants: binucleate cell fusions and hormone production. Placenta 1992, 13: 101-113.

[51] Wooding FBP, Roberts RM, Green JA. Light and electron microscope immunocytochemical studies of the distribution of Pregnancy Associated Glycoproteins (PAGs) throughout pregnancy in the cow: possible functional implications. Placenta 2005, 26, 807-827.

[52] Majewska M, Panasiewicz G, Klisch K, Palomino VJM, Abd-Elnaeim MM, Borkowski K, Szafranska B. Application of complementary DNA of porcine pregnancy-associated glycoproteins as useful probes for the discovery of related transcripts in various Artiodactyla. 7th International Conference on Pig Reproduction, Rolduc, Kerkrade, Netherlands, 2005, p 120.

[53] Enders AC, Liu IK. Trophoblast-uterine interactions during equine chorionic girdle cell maturation, migration, and transformation. Am J Anat 1991, 192: 366-381

[54] Gerstenberg C, Allen WR, Stewart F. Cell proliferation patterns during development of the equine placenta. J Reprod Fertil 1999, 117: 143-152. 
[55] Allen WR. Hormonal control of early pregnancy in the mare. Anim Reprod Sci 1984 7: 283-304.

[56] Do HJ, Kim JH, Abeydeera LR, Han YM, Matteri RL, Green JA, Roberts RM, Day BN, Prather RS. Expression of pregnancyassociated glycoprotein 1 and 2 genes in in vivo, in vitro and parthenogenetically derived preimplantation pig embryos. Zygote 2001, 9: 245-250.

[57] Telford NA, Watson AJ, Schultz GA Transition from maternal to embryonic control in early mammalian development: a comparison of several species. Mol Reprod Dev 1990, 26: 90-100.

[58] Geisert RD, Renegar RH, Thatcher WW, Roberts RM, Bazer FW. Establishment of pregnancy in the pig: I. Interrelationships between preimplantation development of the pig blastocyst and uterine endometrial secretion. Biol Reprod 1982, 27: 925-939.

[59] Mattson BA, Overstrom EW, Albertini DF. Transitions in trophectoderm cellular shape and cytoskeletal organization in the elongating pig blastocyst. Biol Reprod 1990, 42: $195-205$

[60] Denker HW. Implantation: a cell biological paradox. J Exp Zool, 1993, 266: 541-558.

[61] Keys JL, King GJ. Microscopic examination of porcine conceptus-maternal interface between days 10 and 19 of pregnancy. Am J Anat 1990, 188: 221-238.

[62] Samuel CA, Perry JS. The ultrastructure of pig trophoblast transplanted to an ectopic site in the uterine wall. J Anat 1972, 113: 139-149.

[63] Szafranska B, Panasiewicz G, Majewska M, Beckers JF. Chorionic expression of heterogeneous products of the PAG (Pregnancy-Associated Glycoprotein) gene family secreted in vitro throughout embryonic and foetal development in the pig. Reprod Nutr Devel 2003, 43: 497-516.

[64] Szafranska B, Majewska M, Panasiewicz G. N-glycodiversity of the PregnancyAssociated Glycoprotein family (PAG) produced in vitro by trophoblast and trophectoderm explants during implantation, placentation and advanced pregnancy in the pig. Reprod Biol 2004, 4: 67-89.

[65] Godkin JD, Bazer FW, Lewis GS, Geisert RD, Roberts RM. Synthesis and release of polypeptides by pig conceptuses during the period of blastocyst elongation and attachment. Biol Reprod 1982, 27: 977-987.

[66] Godkin JD, Bazer FW, Roberts RM. Protein production by cultures established from day
14-16 sheep and pig conceptuses. J Reprod Fertil 1985, 74: 377-382.

[67] Baumbach GA, Climer AH, Bartley NG, Kattesh HG, Godkin JD. Purification, characterization, and immunocytochemical localization of the major basic protein of pig blastocysts. Biol Reprod 1988, 39: 1171-1182.

[68] Dore JJ Jr, Kattesh HG, Godkin JD Isolation and identification of porcine embryonic basic protein as a fragment of pregnancy-associated glycoprotein-2. Int. J Biochem Cell Biol 1996, 28: 1249-1255.

[69] Sasser RG, Crock J, Ruder-Montgomery CA. Characteristics of pregnancy-specific protein B in cattle. J Reprod Fertil 1989, 37: 109-113.

[70] Willard ST, White DR, Wesson CAR, Stellflug J, Sasser RG. Detection of fetal twins in sheep using radioimmunoassay for pregnancy-specific protein B. J Anim Sci 1995, 73: 960-966.

[71] Xie S, Nagel RJ, Green J, Beckers JF, Roberts RM. Trophoblast-specific processing and phosphorylation of pregnancyassociated glycoprotein-1 in Day 15 to 25 sheep placenta. Biol Reprod 1996, 54: 122-129.

[72] Garbayo JM, Remy B, Alabart JL, Folch J, Wattiez R, Falmagne P, Beckers JF. Isolation and partial characterization of a pregnancy-associated glycoprotein family from the goat placenta. Biol Reprod 1998, 58: 109-115.

[73] Huang F, Cockrell DC, Stephenson TR, Noyes JH, Sasser RG. Isolation, purification, and characterization of pregnancyspecific protein B from elk and moose placenta. Biol Reprod 1999, 61: 1056-1061.

[74] Barbato O, Sousa NM, Malfatti A, Beckers JF, De Santis G, Debenetti A. Purification of Pregnancy-associated glycoproteins (PAGs) in buffalo (Bubalus bubalis): preliminar results. In: Atti II Congresso Nazionale sull'Allevamento del Bufalo, Roma, Italy, 2003, pp 279-283.

[75] Sousa NM, Remy B, El Amiri B, De Figueiredo JR, Banga-Mboko $\mathrm{H}$, Dias Goncalves PB, Beckers JF. Characterization of pregnancy-associated glycoproteins extracted from zebu (Bos indicus) placentas removed at different gestational periods. Reprod Nutr Dev 2002, 42: 227-241.

[76] El Amiri B, Remy B, de Sousa NM, Joris B, Ottiers NG, Perenyi Z, Banga-Mboko $\mathrm{H}$, Beckers JF. Isolation and partial characterization of three pregnancy-associated 
glycoproteins from the ewe placenta. Mol Reprod Dev 2003, 64: 199-206.

[77] El Amiri B, Sousa NM, Mecif K, Desbuleux H, Banga-Mboko H, Beckers JF. Double radial immunodiffusion as a tool to identify pregnancy-associated glycoproteins in ruminant and non-ruminant placentae. Theriogenology 2003, 59: 1291-1301.

[78] El Amiri B, Remy B, De Sousa NM, Beckers JF. Isolation and characterization of eight pregnancy-associated glycoproteins present at high levels in the ovine placenta between day 60 and day 100 of gestation. Reprod Nutr Dev 2004, 44: 169-181.

[79] Klisch K, De Sousa NM, Beckers JF, Leiser R, Pich A. Pregnancy associated glycoprotein-1, -6, -7, and -17 are major products of bovine binucleate trophoblast giant cells at midpregnancy. Mol Reprod Dev 2005, 71: 453-460.

[80] Green JA, Parks T, Avalle MP, Telugu BP, McLain AL, Peterson AJ, McMillan W, Mathialagan N, Hook RR, Xie S, Robert RM. The establishment of an ELISA for the detection of pregnancy-associated glycoproteins (PAGs) in the serum of pregnant cows and heifers. Theriogenology 2005, 63: 1481-1503.

[81] Panasiewicz G, Majewska M, Szafranska B. The involvement of luteinizing hormone (LH) and Pregnancy-Associated Glycoprotein family (PAG) in pregnancy maintenance in the pig. Reprod Biol 2004, 4: 143-163.

[82] Szafranska B, Ziecik A, Okrasa S. Primary antisera against selected steroids or proteins and secondary antisera against $\gamma$-globulins - an available tool for studies of reproductive processes. Reprod Biol 2002, 2: 187-204.

[83] Majewska M, Gizejewski Z, Panasiewicz G, Borkowski K, Szafranska B. Double fluorescent immunohistochemistry (dF-IHC) of the Pregnancy-Associated Glycoprotein (PAG) family expression in domestic and relative wild Artiodactyla species. BASE 2004, 8: 55.

[84] Majewska M, Panasiewicz G, Klisch K, Olivera L, Abd-Elnaeim MM, Borkowski K, Szafranska B. Pregnancy-Associated Glycoproteins (PAG) in Camelids. Reprod Domest Anim 2004, 39: 282-283.

[85] Gosh D, Sengupta J. Recent developments in endocrinology and paracrinology of blastocyst implantation in the primate. Hum Reprod Update 1998, 4: 153-168.
[86] Bartol FF, Wiley AA, Spencer TE, Vallet JL, Christenson RK. Early uterine development in pigs. J Reprod Fertil 1993, 48: 99-116.

[87] Kim HS, Lee GS, Hyun SH, Nam DH, Lee SH, Jeong YW, Kim S, Kim JH, Kang SK, Lee BC, Hwang WS. Embryotropic effect of glycosaminoglycans and receptors in development of porcine pre-implantation embryos. Theriogenology 2005, 63: 1167-1180.

[88] Klisch K, Leiser R. In bovine binucleate trophoblast giant cells, pregnancyassociated glycoproteins and placental prolactin-related protein-I are conjugated to asparagine-linked $\mathrm{N}$-acetylgalactosaminyl glycans. Histochem Cell Biol 2003, 119: 211-217.

[89] Patel OV, Takahashi T, Imai K, Hashizume K. Characterization of native and recombinant bovine pregnancy-associated glycoproteins. Res Vet Sci 2004, 77: 203-210.

[90] Jonker FH. Fetal death: comparative aspects in large domestic animals. Anim Reprod Sci 2004, 82-83: 415-430.

[91] Humblot P. Use of pregnancy specific proteins and progesterone assays to monitor pregnancy and determine the timing, frequencies and sources of embryonic mortality in ruminants. Theriogenology 2001, 56: 1417-1433.

[92] Pope WF. Embryonic mortality in swine. Embryonic mortality in domestic species. Editors: ZAVY MT, Geisert RD. Boca Raton, FL, CRC Press, 1994, 53-77.

[93] Roberts RM, Xie S, Trout WE. Embryouterine interactions in pigs during week 2 of pregnancy. J Reprod Fertil. 1993, 48: $171-186$.

[94] Zoli AP, Demez P, Beckers JF, Reznik M, Beckers A. Light and electron microscopic immunolocalization of bovine Pregnancy Associated Glycoprotein in the bovine placentome. Biol Reprod 1992, 46: 623-629.

[95] El Amiri B, Sousa NM, Perenyi Z, Banga-Mboko H, Beckers JF. Pregnancyassociated glycoproteins in Bos taurus taurus and Bos taurus indicus. Theriogenology 2000, 53: 283.

[96] Szenci O, Beckers JF, Humblot P, Sasser G, Taverne MA, Varga J, Baltusen R, Schekk $\mathrm{G}$. Comparison of ultrasonography, bovine pregnancy-specific protein $\mathrm{B}$, and bovine pregnancy-associated glycoprotein 1 tests for pregnancy detection in dairy cows. Theriogenology 1998, 50: 77-88. 
[97] Zoli AP, Guilbault LA, Delabaut P, Orates WEB, Beckers JF. Radioimmunoassay of a bovine pregnancy-associated glycoprotein in serum: its application for pregnancy diagnosis. Biol Reprod 1992, 46: 83-92.

[98] Chauvin C, Camous S, Gillard P, Maugrion P, Robert C, Foulley JL. PSP60 profile and its variation factors and application to twinning diagnosis in a beef suckling herd application to twinning diagnosis in a beef suckling herd. Revue Med Vet 1999, 150: 143-150.

[99] Gajewski Z, Beckers JF., Melo De Sousa N, Thun R, Sulon J, Faundez R. Determination of pregnancy associated glycoprotein concentrations in sheep, a retrospective study. Adv Cell Biol 1999, 26: 89-96.

[100] Karen A, Kovacs P, Beckers JF, Szenci O. Pregnancy diagnosis in sheep: review of the most practical methods. Acta Vet Brno 2001, 70: 115-126.

[101] Mitchell LM, Silveira M, Mylne MJ, Matthews K, Dingwall WS. Seasonal differences in lamb birthweight do not arise from inherent differences in the oocyte and/or early embryo. Reprod Fertil Dev 2002, 14: 207-213.

[102] Ranilla MJ, Sulton J, Carro MD, Mantecon AR, Beckers JF. Plasma profiles of pregnancy-associated glycoprotein and progesterone levels during gestation in Churra and Merino sheep. Theriogenology 1994, 42: 537-545.

[103] Ruder CA, Stellflug JN, Dahmen JJ, Sasser RG. Detection of pregnancy in sheep by radioimmunoassay of sera for pregnancyspecific protein B. Theriogenology 1988, 29: 905-911.

[104] Wallace JM, Aitken RP, Cheyne MA, Humblot P. Pregnancy-specific protein B and progesterone concentrations in relation to nutritional regimen, placental mass and pregnancy outcome in growing adolescent ewes carrying singleton fetuses. J Reprod Fertil 1997, 109: 53-58.

[105] Fernandez-Arias A, Alabart JL, Folch J, Beckers JF. Interspecies pregnancy of Spanish ibex (Capra pyrenaica) fetus in domestic goat (Capra hircus) recipients includes abnormally high plasmatic levels of pregnancy-associated glycoprotein. Theriogenology 1999, 51: 1419-1430.

[106] Folch J, Benitez W, Alabart JL, Beckers JF. Determination de la concentration plasmatica de PAG (Pregnancy-Associated Glycoprotein) en cabras blanca celtiberica y su utilizacion como diagnostico de gestation. ITEA 1993, 12: 364-366.
[107] Haigh JC, Gates C, Ruder CA, Sasser RG. Diagnosis of pregnancy in wood bison using a bovine assay for pregnancyspecific protein B. Theriogenology 1991, 36: 749-754.

[108] Haigh JC, Dalton WJ, Ruder CA, Sasser RG. Diagnosis of pregnancy in moose using a bovine assay for pregnancy-specific protein B. Theriogenology 1993, 40: 905-911.

[109] Willard ST, Sasser RG, Gillespie JC, Jaques JT, Welsh TH Jr, Randel RD. Methods for pregnancy determination and the effects of body condition on pregnancy status in rocky mountain elk (Cervus elaphus Nelsoni). Theriogenology 1994, 42: 1095-1102.

[110] Osborn DA, Beckers JF, Sulon J, Gassett JW, Muller LI, Murphy BP, Miller KV, Marchinton RL. Use of glycoprotein assays for pregnancy diagnosis in white-tailed deer. J Wildl Manage 1996, 60: 388-393.

[111] Wood AK, Short RE, Darling A, Dusek GL, Sasser RG, Ruder CA. Serum assays for detecting pregnancy in mule and white-tailed deer. J Wildl Manage 1986, 50: 684-687.

[112] Haigh JC, Cranfield M, Sasser RG. Estrus synchronization and pregnancy diagnosis in red deer. J Zoo Anim Med 1988, 19: 202-207.

[113] Willard ST, Hughes DM, Bringans M, Sasser RG, White DR, Jaques JT, Godfrey RW, Welsh THJr, Randel RD. Artificial insemination, hybridization and pregnancy detection in sika deer. Theriogenology 1996, 46: 779-789.

[114] Willard ST, Sasser RG, Gillespie JC, Jaques JT, Welsh TH Jr, Randel RD. Early pregnancy detection and embryonic mortality in fallow deer (Dama dama). J Anim Sci 1994, 72: 67.

[115] Willard ST, Sasser RG, Jaques JT, White DR, Neuendorff DA, Randel RD. Early pregnancy detection and the hormonal characterization of embryonic-fetal mortality in Fallow Deer (Dama dama). Theriogenology 1998, 49: 861-869.

[116] Houston BD, Robbins CT, Ruder CA Sasser RG. Pregnancy detection in mountain goats by assay for PSPB. J Wildl Manage 1986, 50: 740-742.

[117] Batalha ES, Sulon J, Figueiredo JR, Beckers JF, Espeschit CJB, Martins R, Silva LDM. Plasma profile of pregnancy associated glycoprotein (PAG) in pregnant Alpine goats using two radioimmunoassay (RIA) systems. Small Rumin Res 2001, 42: 111-118. 
[118] Batalha ES, Sulon J, Figueiredo JR, Beckers JF, Martins R, Silva LDM. Relationship between maternal concentration of caprine pregnancy-associated glycoprotein in Alpine goats and the number of fetuses using a homologous radioimmunoassay. Small Rumin Res 2001, 42: 105-109.

[119] Humblot P, De Montigny G, Jeanguyot N, Tetedoie F, Payen B, Thibier M, Sasser RG. Pregnancy-specific protein B and progesterone concentrations in French Alpine goats throughout gestation. J Reprod Fertil 1990, 89: 205-212.

[120] Gonzalez F, Sulon J, Calero P, Batista M, Gracia A, Beckers JF. Pregnancyassociated glycoproteins (PAG) detection in milk samples for pregnancy diagnosis in dairy goats. Theriogenology 2001, 56: 671-676.

[121] Gonzalez F, Cabrera F, Batista M, Rodriguez N, Alamo D, Sulon J, Beckers JF, Gracia A. A comparison of diagnosis of pregnancy in the goat via transrectal ultrasound scanning, progesterone, and pregnancy-associated glycoprotein assays. Theriogenology 2004, 62: 1108-1115.

[122] Szenci O, Beckers JF, Sulon J, Bevers MM, Borzsonyi L, Fodor L, Kovacs F, Taverne MAM. Effect of induction of late embryonic mortality on plasma profiles of Pregnancy Associated Glycoprotein 1 in heifers. Vet J 2003, 165: 307-313.

[123] Dosogne H, Massart-Leen AM, Bervenich C. Immunological aspects of pregnancyassociated glycoproteins. Adv Med Biol 2000, 480: 295-305.

[124] Del Vecchio RP. Effect of pregnancyspecific protein $\mathrm{B}$ on prostaglandin $\mathrm{F} 2$ alpha and prostaglandin E2 release by day 16-perifused bovine endometrial tissue. Prostaglandins 1990, 40: 271-282.

[125] Del Vecchio RP, Sutherland WD, Sasser RG. Effect of pregnancy-specific protein B on luteal cell progesterone, prostaglandin, and oxytocin production during two stages of the bovine estrous cycle. J Anim Sci 1995, 73: 2662-2668.

[126] Del Vecchio RP, Sutherland WD, Sasser $\mathrm{RG}$. Bovine luteal cell production in vitro of prostaglandin E2, oxytocin and progesterone in response to pregnancy-specific protein B and prostaglandin F2 alpha. J Reprod Fertil 1996, 107: 131-136.

[127] Weems YS, Bridges PJ, Tanaka Y, Sasser RG, LeaMaster BR, Vincent DL, Weems CW. PGE1 or PGE2 not LH regulates secretion of progesterone in vitro by the 88-90 day ovine corpus luteum of pregnancy. Prostaglandins 1997, 53: 337-353.

[128] Weems YS, Bridges PJ, LeaMaster BR, Sasser RG, Vincent DL, Weems CW. Secretion of progesterone, estradiol-17beta, PGE, PGF2alpha, and pregnancy-specific protein B by 90 -day intact and ovariectomized pregnant ewes. Prostaglandins Other Lipid Mediat 1999, 58: 139-148.

[129] Weems YS, Kim L, Humphreys V, Tsuda $\mathrm{V}$, Weems CW. Effect of luteinizing hormone $(\mathrm{LH})$, pregnancy specific protein $\mathrm{B}$ (PSPB), or arachidonic acid (AA) on ovine endometrium of the estrous cycle or placental secretion of prostaglandins E2 (PGE2) and F2alpha (PGF2alpha) and progesterone in vitro. Prostaglandins Other Lipid Mediat. 2003, 71: 55-73.

[130] Austin KJ, King CP, Vierk JE, Sasser RG, Hansen TR. Pregnancy-specific protein B induces release of an alpha chemokine in bovine endometrium. Endocrinology 1999, 140: 542-545.

[131] Teixeira MG, Austin KJ, Perry DJ, Dooley VD, Johnson GA, Francis BR, Hansen TR. Bovine granulocyte chemotactic protein-2 is secreted by the endometrium in response to interferon-tau (IFN-tau). Endocrine 1997, 6: 31-37.

[132] Panasiewicz G, Majewska M, Romanowska A, Dajnowiec J, Szafranska B. Radiocompetition of secretory pregnancyassociated glycoproteins as chorionic ligands with luteal and uterine gonadotrophin receptors of pregnant pigs. Anim Reprod Sci 2006 (in press).

[133] Szafranska B, Panasiewicz G, Majewska M, Romanowska A, Dajnowiec J. Pregnancy-associated glycoprotein family (PAG) as chorionic signaling ligands for gonadotropin receptors of cyclic animals. Anim Reprod Sci 2006 (in press). 